\title{
PENGARUH SUHU INKUBASI TERHADAP AKTIVITAS LIPASE DAUN PEPAYA (Carica papaya L) YANG DIAMOBILISASI DALAM PASIR LAUT
}

\section{[Influence of Incubation Temperature on Sea Sand Immobilized Lipase from Papaya Leaf (Carica papaya L)]}

\author{
Fisty Sumangkut ${ }^{{ }^{\star}}$, Nurhaeni ${ }^{1}$, Ni Ketut Sumarni ${ }^{1}$, Erwin Abdul Rahim ${ }^{1}$ \\ 1) Jurusan Kimia, Fakultas MIPA, Universitas Tadulako, Palu \\ J. Soekarno Hatta Km.9, Kampus Bumi Tadulako Tondo Palu, Telp. 0451- 422611 \\ *)Coresponding author: Fistysumangkut@gmail.com (082293684139)
}

Diterima 22 Mei 2018, Disetujui 7 Mei 2019

\begin{abstract}
The silica content in sea sand can be used to immobilize lipase from papaya leaf. Research on the influence of incubation temperature on sea sand immobilized lipase from papaya leaf (Carica papaya $\mathrm{L}$ ) has been carried out. The aim of research is determining the influence of incubation temperature on sea sand immobilized lipase from papaya leaf (Carica papaya $\mathrm{L}$ ). The method used in this study was a completely randomized design with temperature at $30,40,50,60,70^{\circ} \mathrm{C}$. The results show that lipase from papaya leaf (Carica papaya $L$ ) had successfully immobilized in the sea sand and the optimum temperature stability of lipase immobilized in sea sand at $50^{\circ} \mathrm{C}$ with an activity is $53.000 \mu \mathrm{mol} / \mathrm{g} . j a \mathrm{~m}$
\end{abstract}

Keywords : immobilized, lipase, papaya leaf, sea sand.

\begin{abstract}
ABSTRAK
Pasir laut mengandung silika yang dapat digunakan untuk amobilisasi enzim lipase dari daun papaya. Penelitian yang telah dilakukan tentang pengaruh suhu inkubasi terhadap aktivitas lipase daun pepaya (Carica papaya L) yang diamobilisasi dalam pasir laut. Penelitian ini bertujuan untuk mengetahui pengaruh suhu terhadap aktivitas lipase daun pepaya yang diamobilisasi pasir laut. Metode penelitian menggunakan Rancangan Acak Lengkap (RAL) dan dilakukan variasi suhu 30, 40, $50,60,70{ }^{\circ} \mathrm{C}$. Hasil penelitian menunjukan bahwa enzim lipase teramobilisasi pasir laut memiliki kestabilan suhu optimum $50^{\circ} \mathrm{C}$ dengan aktivitas lipase sebesar $53.000 \mu \mathrm{mol} / \mathrm{g}$.jam.
\end{abstract}

Kata Kunci : Amobilisasi, lipase, daun papaya, pasir laut. 


\section{LATAR BELAKANG}

Indonesia keanekaragaman flora yang sangat tinggi. Dari sekian banyak tumbuhan, sekitar 9.600 spesies memiliki khasiat sebagai obat, salah satunya tanaman pepaya. Pepaya adalah jenis tanaman yang kaya akan vitamin, ineral dan senyawa metabolit sekunder lainhya yang memiliki manfaat untuk kesehatan. Seluruh bagian tanaman papaya dapat dimanfaatkan sebagai obat tradisional. Daun tanaman pepaya mengandung lipase dapat diperoleh hampir dari semua bagian tanaman pepaya yaitu, getah, daun, buah muda dan tangkai.

Lipase (E.C 3.1.1.3) termasukan dalam golongan enzim hydrolase yang berfungsi untuk menghidrolisis senyawa trigliserida. Keunggulan enzim lipase sebagai biokatalisator dibandingkan katalis kimia adalah aktivitas katalik enzim yang tinggi, bekerja secara spesifik, dapat bekerja pada suhu yang relatif rendah sekitar $30^{\circ} \mathrm{C}$ dibandingkan katalis kimia yang bekerja pada suhu $(220-250)^{\circ} \mathrm{C}$. Peningkatan nilai guna lipase dapat dilakukan dengan metode imobilisasi.

Ammobilisasi enzim adalah suatu proses penahanan pergerkan molekul enzim pada tempat tertentu dalam suatu ruang reaksi kimia sehingga membuat enzim menjadi stabil dan lebih mudah dipisahkan dari campuran pada akhir reaksi untuk reaksi selanjudnya. Salah satu metode amobilisasi enzim yang sederhana dam cukup menguntungkan adalah metode penjerapan fisik, yaitu menggunakan adsorben atau agen penjerap yang bekerja dengan menjerap ataupun menempelkan enzim dipermukaannya. Penggunakan adsorben sebagai matriks amobilisasi dapat disubtitusi dengan menggunakan pasir laut karena menggandung silica 60-98\%, sehingga baik jika dimanfaatkan sebagai matriks amobilisasi (Ardian et al., 2014). Jenis adsorben yang dapat dimanfaatkan adalah adsorben anorganik, seperti pasir laut.

Berdasarkan uraian tersebut, dalam penelitian akan dilakukan kajian pengaruh suhu inkubasi terhadap aktivitas lipase daun pepaya (Carica papaya L) yang diamobilisasi dalam pasir laut.

\section{METODE PENELITIAN}

\section{Bahan dan Peralatan}

Bahan yang digunakan pada penelitian ini yakni daun papaya (Carica papaya L), pasir laut, $\mathrm{CaCl}_{2}$, amonium sulfat, minyak sawit (Bimoli), indikator fenolftalein, $\mathrm{NaOH} 1 \mathrm{M}, \mathrm{HCl} 0,1$ $M$, alumunium foil, aseton, etanol, buffer fosfat kalium $\mathrm{pH} 7$, dan aquades.

Peralatan yang digunakan pada penelitian ini yakni blender (Miyako 152GF), ayakan 120 mesh (Stainless), neraca analitik (Ohaus Corp. Pine Brook NJ USA), mesin kocok (KJ-201BD Made in W Germany), corong buchner (Iwaki Asahi Glass Made in Japain, Tokyo Rikakikai), $\mathrm{pH}$ meter (Lamotte), thermoshaker (Gerhardt), statif dan klem, dan alat-alat 
gelas yang umum digunakan dalam laboratorium.

\section{Prosedur Penelitian}

\section{Pengujian Aktivitas Enzim Lipase Daun Pepaya (Nurhaeni et al., 2017)}

Lipase daun pepaya muda dikeringkan dengan sinar matahari kemudian dibuat menjadi tepung yang selanjutnya disebut tepung daun pepaya. Tepung daun pepaya dicampur dengan $\mathrm{CaCl}_{2} \quad 0,01 \mathrm{M}$ dengan rasio 1:10. Campuran selanjutnya dikocok diatas mesin kocok agitasi $300 \mathrm{rpm}$ selama 3 jam, kemudian disaring untuk memisahkan ekstrak enzim dari ampas daun. Enzim lipase dalam ekstrak dipisahkan melalui pengendapan menggunakan ammonium sulfat $65 \%$ jenuh. Endapan enzim disuspensikan ke dalam larutan $\mathrm{CaCl}_{2}$ 0,01 M dengan konsentrasi $50 \%$. Suspensi enzim diuji aktivitasnya menggunakan substrat minyak sawit. Dimasukan 5 gram minyak bimoli dalam Erlenmeyer $250 \mathrm{~mL}$ ditambahkan air $50 \mathrm{~mL}$. Campuran dihomogenkan dan ditambahkan suspensi enzim sebanyak $10 \mathrm{~mL}$. Campuran dikocok diatas mesin kocok dengan agitasi $300 \mathrm{rpm}$ selama 1 jam pada suhu $30^{\circ} \mathrm{C}$. Kemudian ditambahkan indikator pp sebanyak 3 tetes dan dititrasi dengan $\mathrm{NaOH} 1 \mathrm{M}$. Prosedur yang sama diulang dengan suhu $40^{\circ} \mathrm{C}, 50^{\circ} \mathrm{C}, 60^{\circ}$ dan $70^{\circ} \mathrm{C}$.

Aktivitas Enzim Lipase $(\mu \mathrm{mol} / \mathrm{jam})=$

Volume $\mathrm{NaOH}(\mathrm{mL}) \times \mathrm{M} \mathrm{NaOH}(\mathrm{mol} / \mathrm{L}) \times 1000$ Waktu reaksi(jam)

\section{Imobilisasi Lipase dengan Pasir Laut}

Imobilisasi dilakukan berdasarkan metode Ardian et al. (2014) dengan beberapa modifikasi. Lipase ekstrak kasar sebanyak $40 \mathrm{~mL}$ dicampurkan dengan 10 $g$ pasir laut yang telah diaktivasi. Diinkubasi pada suhu ruang dengan kecepatan 100 rpm selama 3 jam. Hasil amobilisasi kemudian disaring dengan kertas saring sehingga dihasilkan filtrat dan endapan. Endapan sebagai lipase amobil diuji kestabilan aktivitasnya berdasarkan pengaruh suhu inkubasi.

\section{Analisis Aktivitas Enzim Lipase Terimobilisasi Pasir Laut}

Penentuan aktivitas enzim lipase dilakukan sesuai metode Nurhaeni et al. (2017) dengan beberapa modifikasi. 5 gram minyak bimoli, $40 \mathrm{~mL}$ buffer fosfat kalium $\mathrm{pH}$ 7. Sebanyak $10 \mathrm{~mL}$ enzim lipase ditambahkan dalam larutan lalu diinkubasi selama 1 jam pada suhu $30^{\circ} \mathrm{C}$. Selanjutnya Reaksi dihentikan dengan menambahkan $10 \mathrm{~mL}$ campuran aseton : etanol $(1: 1 \mathrm{v} / \mathrm{v})$. Kemudian sampel dititrasi menggunakan $\mathrm{NaOH} 1 \mathrm{M}$ menggunakan indicator fenolftalein hingga titik akhir berwarna merah muda. Prosedur yang sama diulang dengan suhu $40^{\circ} \mathrm{C}, 50^{\circ} \mathrm{C}$, $60^{\circ} \mathrm{C}$, dan $70^{\circ} \mathrm{C}$. Untuk blangko dilakukan prosedur yang sama tanpa perlakuan penambahan enzim.

Aktivitas Enzim Lipase $(\mu \mathrm{mol} / \mathrm{jam})=$ Volume $\mathrm{NaOH}(\mathrm{mL}) \times \mathrm{M} \mathrm{NaOH}(\mathrm{mol} / \mathrm{L}) \times 1000$ Waktu reaksi(jam) 


\section{HASIL DAN PEMBAHASAN}

Aktivitas enzim lipase tanpa pasir laut dengan variasi suhu $30^{\circ} \mathrm{C}, 40^{\circ} \mathrm{C}$, $50^{\circ} \mathrm{C}, 60^{\circ} \mathrm{C}$, dan $70^{\circ} \mathrm{C}$ yang diperoleh secara berturut-turut $8133,33 \mathrm{~mol} / \mathrm{jam}$, $8.6000 \mu \mathrm{mol} / \mathrm{jam}, \quad 8116,67 \mu \mathrm{mol} / \mathrm{jam}$, 7666,67 $\mu \mathrm{mol} / \mathrm{jam}$ dan $7200 \mu \mathrm{mol} / \mathrm{jam}$.

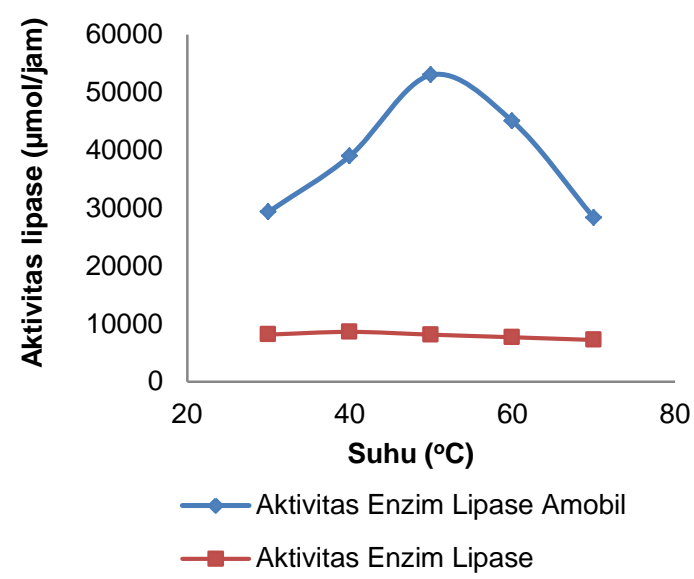

Gambar 1 Aktivitas lipase pada berbagai suhu imobilisasi

.Pada pengujian aktivitas enzim lipase teramobil pasir laut hasil yang diperoleh pada suhu $30^{\circ} \mathrm{C}$ aktivitas enzim lipase dari daun pepaya yang diamobilisasi dalam pasir laut adalah sebesar 29333,33 $\mu \mathrm{mol} / \mathrm{jam}$ sedangkan pada suhu $50^{\circ} \mathrm{C}$ aktivitas enzim mengalami peningkatan sebesar 53000 $\mu \mathrm{mol} / \mathrm{jam}$, namun pada suhu $70^{\circ} \mathrm{C}$ aktivitas enzim mengalami penurunan yang signifikan yaitu sebesaar 28333,33 $\mu \mathrm{mol} / \mathrm{jam}$. Hal ini menunjukan bahwa suhu berperan sangat penting dalam reaksi enzimatik, karena enzim juga merupakan suatu protein yang sangat rentan terhadap kondisi lingkungan. Adanya perubahan suhu lingkungan akan mengakibatkan aktivitas enzim ikut mengalami perubahan.
Enzim dapat mencapai aktivitas optimum pada suhu tertentu yang dikenal sebagai suhu optimum (Bidiman dan Setiawan, 2010). Energi kinetik akan semakin bertambah dengan bertambahnya suhu hingga mecapai suhu optimumnya. Bertambahnya energi kinetik menyebabkan gerak vibrasi, translasi, dan rotasi enzim maupun substrat menjadi semakin cepat. Pada kondisi demikian, maka peluang enzim dan substrat untuk bereaksi semakin besar (Meryandini et al., 2009). Selain itu, frekuensi tumbukan antara molekul enzim dan substrat juga semakin tinggi, sehingga enzim menjadi aktif. Pada saat suhu telah melebihi batas optimum, maka enzim akan mengalami denaturasi, sehingga aktivitas katalisis dari semakin menjadi menurun (Hutasoit et al., 2016). Kondisi saat suhu melebihi batas optimumnya juga menyebabkan substrat berubah konformasi, sehingga tidak spesifik terhadap sisi aktif enzim (Meryandini et al., 2009). Padas sat enzim dan substrat tidak berinteraksi secara spesifik, maka konsentrasi produk menjadi rendah.

Suhu optimum setiap enzim berbeda satu sama lain, sebagian besar enzim memiliki aktivitas optimum pada suhu 30$50^{\circ} \mathrm{C}$ yang masuk dalam golongan mesozim (Volk dan Wheeler, 1984), sedangkan enzim yang memiliki aktivitas optimum diatas $80^{\circ} \mathrm{C}$ disebut hipertermozim (Meryandini et al., 2009). Oleh karena itu, pada penelitian ini kestabilan enzim lipase daun pepaya 
(Carica papaya L) diimobilisasi dalam pasir laut berdasarkan suhu inkubasi termasuk dalam golongan mesozim atau disebut juga enzim yang stabil pada suhu sedang karena dapat bekerja optimum pada suhu $50^{\circ} \mathrm{C}$.

Hasil penelitian aktivitas enzim lipase tanpa pasir laut jauh lebih rendah aktivitasnya dibandingkan dengan aktivitas enzim lipase menggunakan pasir laut. Pasir laut mengandung silika 60-98\%, sehingga baik jika dimanfaatkan sebagai matriks amobilisasi. Material pasir laut juga memiliki ruang pengunci. Aktivasi pasir laut dapat dilakukan melalui proses fisika dan kimia. Pengaktifan secara fisika dilakukan dengan pemanasan yang bertujuan untuk menguapkan molekulmolekul air, sedangkan aktivasi secara kimia menggunakan zat kimia baik garamn asam maupun basa (Ardian et al., 2014).

\section{KESIMPULAN}

Enzim lipase teramobilisasi pasir laut memiliki suhu optimum $50^{\circ} \mathrm{C}$ dengan aktivitas lipase sebesar yaitu 53.000 Hmol/ jam.

\section{DAFTAR PUSTAKA}

Ardian, A., Roosdiana, A., Sutrisno. 2014. Pengaruh Suhu dan Lama Penyimpanan Terhadap Kestabilan Aktivitas Xilanase Diamobilisasi Dalam Pasir Laut. Kimia.Student Journal, 2(1): 386 -392.

Bidiman, A dan Setyawan, S 2010. Pengaruh Konsentrasi Substrat, Lama Inkubasi dan pH dalam Proses Isolasi Enzim Xylanase dengan Menggunakan Media Jerami Padi. Jurnal Teknik Kimia. 11: 1-11.

Hutasoit, N., Ina, P T., Permana, I D G M. 2016. Optimasi $\mathrm{pH}$ dan Suhu Pada Aktivitas Enzim Lipase Dari Biji Kakao (Theobroma cacao L.) Berkapang. ITEPA, 5(2): 95-102.

Nurhaeni., Ridhay, A., Magfira. 2017. Pengaruh Ekstrak Metanol Daun Pepaya (Carica papaya L.) Terhadap Aktivitas Enzim Lipase. KOVALEN, 3(3): 211-222.

Meryandini, A. Widosari, $W$ dan Maranatha, B. 2009. Isolasi Bakteri Selulolitik dan Karekterisasi Enzimnya. Makara Sains. 13 (1): 3338.

Volk dan Wheeler. 1984. Mikrobiologi Dasar Edisi Kelima Jilid I. Jakarta: Erlangga. 